\title{
PEMBELAJARAN MENGGUNAKAN MEDIA SASTRA TRADISIONAL DALAM MENGEMBANGKAN NILAI PERSONAL ANAK USIA DINI
}

\author{
NI WAYAN RASMINI \\ Sekolah Tinggi Agama Hindu Negeri Gde Pudja Mataram \\ Jl.Pancaka No. 7 B Telp. (0370) 628382, Fax. (0370) 631725 \\ Email: wayanrasmini1967@gmail.com
}

\begin{abstract}
The aim of this study was to understand the characteristic of learning plans, learning activities, and learning implications of using traditional literatures as learning media in developing personal values of kindergarten chidren at Cahaya Ananda Kindergarten in Mataram. Personal values purposed in this study were: emotional value, intelegency, imagination, sosial value, ethics, and religious value. Traditional literatures purposed in this study were: mythos, legends, fabels, folklores, folksongs, and wayang stories told generations after generations around children subjected to this study. This study was an ex-post facto descriptive quantitative study. From this study we found that the characteristic of Daily Learning Plans used in subject kindergarten has been appropriate with national Daily Learning Plans now used. Environment oriented prior-to-play learning process was integrated in outside-class initial activities. Teachers have included traditional literatures in learning plans and learning process and have shown to increase children's personal values. At the end of learning process children have shown increase in: emotional value, intelectuality, imagination, empathy, ethics, and religiousity.
\end{abstract}

Keywords: learning media, traditional literatures, personal values

\begin{abstract}
Abstrak: Penelitian ini bertujuan untuk mengetahui: karakteristik rencana pembelajaran, kegiatan pembelajaran, dan implikasi pembelajaran menggunakan media sastra tradisional dalam mengembangkan nilai personal anak usia dini di Taman Kanak-kanak Cahaya Ananda Mataram. Nilai personal terdiri dari: emosi, intelek, imajinasi, rasa sosial, rasa etis dan religius. Sastra tradisional: mitos, legenda, cerita binatang, dongeng, cerita wayang dan nyanyian rakyat yang biasa hidup disekitar anak secara turun-temurun. Menggunakan metode deskriptif kualitatif, dan pendekatan ex-post facto. Ditemukan bahwa: karakteristik RPPH telah mengikuti format RPPH yang sedang berlaku, proses pembelajaran pijakan orientasi lingkungan sebelum bermain digabungkan menjadi kegiatan awal di luar kelas. Sastra Tradisional diinternalisasi oleh guru menjadi rencana pembelajaran dan pelaksanaan pembelajaran, ternyata dapat memberi dampak pada tumbuh-kembang nilai personal anak. Dalam proses belajar dan diakhir pembelajaran dapat diamati tingkah laku anak, telah muncul seperti: emosi, intelek, imajinasi, empati, etis dan religious.
\end{abstract}

Kata Kunci: media, sastra tradisional, nilai personal

\section{Pendidikan Anak usia Dini} (PAUD) merupakan kegiatan yang menjadi tanggung jawab bersama antara keluarga, masyarakat dan pemerintah untuk anak usia 0-6 tahun.

Fenomena menjamurnya PAUD

merupakan salah satu bentuk

antusiame masyarakat dalam 
Pembelajaran Menggunakan Media... Ni Wayan Rasmini

merespon program pemerintah untuk meningkatkan aksesibilitas masyarakat terhadap pendidikan bagi anak usia dini, mengingat masih banyak anak-anak yang masa usia dini belum memperoleh layanan pendidikan anak usia dini. UU RI No. 20/2003 tentang Sistem Pendidikan Nasional, khususnya Pasal 28 ditetapkan bahwa Pendidikan Anak Usia Dini dapat diselenggarakan melalui jalur pendidikan formal, nonformal, dan informal (Wiyani, 2012:16). Pendidikan dan pembelajaran yang digunakan sangat bervariasi tergantung dari karakteristik nilai-nilai kearifan lokal yang telah dibangun oleh leluhur menjadi sebuah identitas, yang digunakan sebagai ideologi masyarakat.

Sastra tradisional diyakini memiliki nilai-nilai yang sangat kaya yang dapat mempengaruhi arah dan tujuan perkembangan kepribadia anak dalam proses menuju kedewasaan yang mempunyai jati diri yang jelas.

Sastra tradisional seperti mitos, legenda, cerita binatang, dongeng, nyanyian rakyat dan sebagainya, yang hidup di dalam suatu masyarakat diyakini oleh masyarakat memiliki nilai-nilai kearifan yang mengkristal di dalamnya, yang dapat digunakan sebagai media pendidikan dan pembelajaran yang cukup efektif untuk menumbuh-kembangkan nilainilai personal anak. Sebagai media pembelajaran dalam tumbuhkembang anak usia dini, maka sastra tradisional perlu diidentifikasi secara akurat tentang jenis-jenis, kandungan nilai-nilainya, bahasa dan alur cerita, penokohan, dan lain sebagainya. Pembelajaran sastra tradisional perlu dikemas dalam bentuk persiapan, pelaksanaan, dan evaluasi pembelajaran yang bermakna untuk pembelajaran anak usia dini.

Rencana

Pelaksanaan Pembelajaran (RPP) dalam Mengembangkan Nilai Personal Anak Usia Dini Menggunakan Sastra Tradisional sebagai Media Pembelajaran. Menurut E. Mulyasa (2009:158), Rencana pelaksanaan pembelajaran pada hakekatnya merupakan perencanaan jangka pendek untuk memperkirakan atau memproyeksikan apa yang akan dilakukan dalam pembelajaran. Rencana pelaksanaan pembelajaran 
Pembelajaran Menggunakan Media... Ni Wayan Rasmini

merupakan keseluruhan proses orang lain dan antar generasi (Burhan pemikiran dan penentuan semua aktivitas yang akan dilakukan pada masa kini dan masa yang akan datang dalam rangka mencapai tujuan.

Menurut

Peraturan

Pemerintah (PP) No 19 tahun 2005 pasal 20 berbunyi bahwa perencanaan proses pembelajaran meliputi silabus dan rencana pelaksanaan pembelajaran yang memuat sekurangkurangnya tujuan pemebelajaran, materi pembelajaran, metode pembelajaran, sumber belajar dan penilaian hasil belajar. Mengidentifikasi kompetensi adalah langkah pertama yang harus dilakukan dalam rencana pelaksanaan pembelajaran, karena kompetensi yang diharapkan dari peserta didik sebagai hasil akhir dari pembelajaran. Karakteristik RPP dalam penelitian ini adalah pengembangan dengan tema sastra tradisional yang dapat membentuk kopetensi diri dalam bentuk nilai personal.

Sastra tradisional merupakan berbagai cerita dan kebiasaan dalam bentuk ekspresi masyarakat pada masa lalu yang umumnya disampaikan secara lisan kepada
Nurgiyantoro, 2005: 163). Pada saat belum dikenal tulisan, ekspresi sastra lisan merupakan satu-satunya sarana paling efektif sebagai sarana komunikasi dan berekspresi sebagai manifestasi eksistensi diri dan kelompok. Sastra tradisional adalah suatu bentuk tuturan lisan yang muncul dan berkembang secara turun-temurun dan tidak disengaja untuk mengungkapkan berbagai gagasan yang sudah muncul sebelumnya, yang pada umumnya digunakan sebagai sarana untuk memberikan pesan moral (Mitchell, 2003: 228). Penokohan dan alur cerita bersifat sederhana dan linier serta menampilkan satu jalinan kisah. Pencerita tidak memiliki kesempatan untuk mengkreasikan tokoh dan alur secara leluasa, tetapi lebih membiarkan tokoh mengikuti alur cerita yang mudah diikuti. Disela-sela alur cerita itu juga tergambar karakter tokoh, diselipi pesan-pesan moral dan pandangan tentang kebenaran. Hal inilah yang ditekankan pada kehadiran cerita tradisional dalam pembelajaran di TK Cahaya Ananda Mataram. Sastra tradisional yang 
Pembelajaran Menggunakan Media... Ni Wayan Rasmini

dipakai sebagai tema dan materi pembelajaran dalam penelitian ini terdiri dari: mitos, legenda, cerita binatang, dongeng, cerita wayang, dan nyanyian rakyat. Yang sangat penting dalam pembelajaran adalah pesan-pesan yang terkandung di dalam cerita, kandungan makna dan pesan moral yang ditawarkan.

Legenda merupakan bagian dari cerita rakyat yang menarik dengan tokoh-tokoh yang hebat yang berada di luar batas-batas manusia lumrah. Legenda tidak mengaitkan tokoh dengan dewa-dewa melainkan mengaitkan dengan tokoh, peristiwa, atau tempat-tempat nyata yang mempunyai kebenaran sejarah. Ada beberapa jenis legenda: legenda tokoh, legenda tempat peninggalan, legenda peristiwa. Legenda juga memuat kepercayaan atau keyakinan masyarakat, dan kepercayaan masyarakat itu memiliki beberapa fungsi diantaranya sebagai alat pelestari ajaran, sebagai bahan pembujuk yang bersifat mitos, menggiring pikiran dan perasaan untuk menanamkan nilai-nilai. Ini berarti sastra lisan bisa digunakan sebagai materi pembelajaran dalam mengembangkan nilai-nilai termasuk nilai personal anak (Sukatman, 2009: 57)

Cerita binatang (fabel) merupakan salah satu bentuk cerita tradisional yang menampilkan binatang sebagai tokoh yang mempersonifikasi manusia, menyangkut penokohan, karakter maupun persoalan hidup yang diungkapnya. Binatang-binatang tersebut dianggap dapat berpikir dan beriteraksi layaknya manusia dengan permasalahan manusia dalam rangka menyampaikan pesan moral dan pelestarian lingkungan, karena dapat mendekatkan antara binatang dengan manusia secara individu maupun masyarakat, sebagaimana yang ditampilkan dalam tokoh cerita, alur cerita dan sebagainya.

Dongeng merupakan salah satu cerita rakyat tradisional dan dipahami sebagai cerita yang tidak benar-benar terjadi dan sering tidak masuk akal. Tokoh dongeng terbelah dua, yaitu yang berkarakter baik dan berkarakter kurang baik.

Cerita wayang pada intinya mengisahkan kepahlawanan para tokoh yang berwatak baik dalam 
Pembelajaran Menggunakan Media... Ni Wayan Rasmini

menghadapi dan menumpas tokoh yang berwatak jahat, mengandung ajaran moral yang diperankan oleh tokoh-tokoh yang sudah jelas karakternya.

Nyanyian rakyat merupakan bentuk sastra tradisional yang banyak dikenal dan dinyanyikan hingga kini, namun tidak diketahui penciptanya. Nyanyian rakyat dapat meresap amat dalam dihati sanubari anggotanya karena mereka sudah mengenal dan menyanyikan sejak kanak-kanak. Berdasarkan konsep teoretis maka pembelajaran menggunakan media sastra tradisional memiliki kekayaan makna dan nilai-nilai, terutama pada anak usia dini, baik nilai pendidikan maupun nilai personal, seperti: perkembangan emosi, intelek, imajinasi, rasa sosial, rasa etis, keindahan, wawasan multicultural dan religius.

Gagne 1970 \& Briggs 1970 dalam Sadiman (2012: 6) menyatakan bahwa media adalah berbagai jenis komponen dalam lingkungan siswa yang dapat merangsang untuk belajar atau segala alat fisik yang dapat menyajikan pesan, serta merangsang siswa untuk belajar. Berdasarkan penjelasan di atas maka sastra tradisional memenuhi kualifikasi sebagai media pembelajaran, karena mengandung unsur yang dapat dilihat, didengar, dibaca, disimak dan dirasakan oleh individu yang memanfaatkannya.

Pelaksanaan Pembelajaran Menggunakan Media Sastra Tradisional dalam Mengembangkan Nilai Personal Anak Usia Dini. Berdasarkan perkembangan kurikulum di Indonesia dari kurikulum berorientasi isi, proses dan saat ini berorientasi kompetensi berdasarkan tema-tema yang bersifat kontekstual untuk membangun nilai personal anak usia dini (Muhaimin Azzet, 2011: 41-47). Pembelajaran sastra tradisional mengandung kearifan lokal, tema-tema yang kontekstual, sehingga dapat meningkatkan kualitas pembelajaran dan efektifitas hasil pembelajaran seperti: rasa percaya diri, kemampuan bekerja sama, kemampuan bergaul, kemampuan berempati dan kemampuan berkomunikasi.

$$
\text { Surya (2006: }
$$

mengemukakan bahwa kecerdasan menyeluruh anak sejak dini tumbuh 
Pembelajaran Menggunakan Media... Ni Wayan Rasmini

sebagai satu sistem, antara kesehatan fisik, mental, hiburan dan percaya diri, maka pengembangan kecerdasan jamak dilakukan dengan berorientasi pada tumbuh-kembang otak. Usaha yang maksimal, melatih berbagai aspek perkembangan, memberi treatment dengan berbagai rangsangan dan mengontrol prilaku.

$$
\text { Model pengembangan }
$$

pembelajaran dapat menggunakan tiga pendekatan: pendekatan yang bersifat situasional, yaitu konsentrasi pembahasan dan intensitas pembelajaran tergantung dari munculnya fenomena yang bersifat situasional pada peserta didik; pendekatan yang bersifat terpisah atau tersendiri, yaitu model pembelajaran yang dikemas secara khusus dan tersendiri berdasarkan karakteristik yang khas dan tuntutan penguasaan yang pasti, dan pelaksanaannya bersifat regular dimana waktu dan tempat telah dirancang sedemikian rupa; pendekatan yang bersifat integrasi, yaitu model pembelajaran yang mengitegrasikan disiplin dan berbagai bidang pengembangan secara sistematis dan formal. Dalam pengorganisasiannya harus mampu melihat secara seksama karakteristik setiap bidang yang diintegrasikan dengan bidang yang dikembangkan (Isjoni, 2010: 100-114). Pembelajaran sastra tradisional yang efetif akan menghasilkan berbagai kemampuan: keterampilan intelektual, strategi kognitif, informasi verbal-fakta, keterampilan motorik, sikap dan nilai yang berhubungan dengan arah dan intensitas emosional yang mempengaruhi kecenderungan dalam hidup bersama dengan orang lain (Mafiroh, 2009: 1-7).

$$
\text { Pembelajaran yang }
$$

menggunakan sastra tradisional sebagai media, sumber dan tema, terjadi interaksi yang koprehensif untuk tumbuh-kembang anak terutama adalah pengembangan sosial-emosional dan moral spiritual yang menjadi dasar dari pendidikan karakter. Agus Wibowo, (2012: 2564) menyatakan bahwa pendidikan dan pembelajaran anak usia dini perlu dilakukan dengan memperhatikan karakteristik anak, fase-fase perkembangan anak, model pembelajaran yang sesuai, dan 
Pembelajaran Menggunakan Media... Ni Wayan Rasmini

pendekatan pembelajaran yang relevan, sehingga dapat menumbuhkembangkan anak yang memiliki nilai-nilai luhur dan karakter yang baik. Alur cerita yang sistematis dan penokohan yang jelas serta struktur cerita yang dibangun dari kearifan lokal akan menjadi tema dan sumber belajar yang cukup memadai, materi yang kontekstual, cerita yang menarik, akan dapat meningkatkan kualitas proses pembelajaran, meningkatkan partisifasi siswa dan mengoptimalkan tumbuh-kembang siswa secara fisik, sosial-emosional, verbal-linguistik dan logikamatematika.

$$
\text { Implikasi Pembelajaran }
$$

Menggunakan Media Sastra

Tradisional dalam Mengembangkan

Nilai Personal Anak Usia Dini. Sastra tradisional diyakini memiliki kontribusi yang besar bagi tumbuhkembang anak dalam proses menuju kedewasaan sebagai manusia yang mempunyai jati diri yang jelas. Kepribadian dan jati diri seorang anak dibentuk dan terbentuk lewat lingkungan baik diusahakan secara sadar maupun tidak. Sastra tradisional dapat berperan sebagai

media baik yang sifatnya tertulis maupun sastra lisan yang diperoleh anak lewat saluran tuturan. Sastra tradisional diyakini mampu dipergunakan sebagai salah satu sarana untuk menanam, memupuk, mengembangkan, dan melestarikan nilai-nilai yang diyakini baik dan berharga oleh masyarakat dan bangsa.

Penanaman nilai-nilai dapat dilakukan sejak anak belum dapat bicara, dan belum dapat membaca. Nyanyian-nyanyian tradisional yang biasa didendangkan seorang ibu untuk membujuk agar si buah hati segera tertidur atau sekedar untuk menyenangkan mereka, pada hakekatnya juga bernilai kesastraan dan sekaligus mengandung nilai yang besar andilnya bagi tumbuh-kembang kejiwaan anak. Huck dkk. (1987) dalam Nurgiyantoro (2005: 36) menyatakan bahwa sastra tradisional memiliki manfaat, fungsi, atau kontribusi secara langsung maupun tak langsung bagi anak. Kontribusi tersebut mulai dari dukungan pertumbuhan nilai (rasa, emosi, dan bahasa), personal (kognitif, sosial, etis dan spiritual), eksplorasi dan penemuan. Indikasi pembelajaran 
Pembelajaran Menggunakan Media... Ni Wayan Rasmini

sastra tradisional dalam pembentukan nilai personal terdiri dari perkembangan emosi, perkembangan intektual, perkembangan imajinasi, pertumbuhan rasa sosial, dan pertumbuhan rasa etis serta religius.

Berdasarkan uraian di atas dapat dipetik pengaruh yang sangat besar keberadaan sastra tradisional terhadap tumbuh-kembang nilai personal anak. Jika pembelajaran yang terdiri dari perencanaan, pelaksanaan dan pengembangan dirancang dengan sengaja dan sadar untuk membangun tumbuh-kembang nilai-nilai personal anak, seperti emosi, intelektual, imajinasi, rasa sosial, rasa etis dan religius maka akan semakin besar manfaatnya.

Hasil Penelitian Ni Wayan Rasmini tahun 2015 menunjukkan bahwa pola asuh demokratis dengan tema aku dan keluargaku sangat tinggi implikasinya pada tumbuhkembang kecerdasan jamak anak usia dini pada keluarga Hindu di Kota Mataram.

Hasil penelitian Yenti Juniarti Jurnal Pendidikan Usia Dini Volume 9 Edisi 2, November 2015 diakses 8 Agustus 2016 menunjukkan peningkatan kecerdasan naturalis dengan metode kunjungan lapangan, pra-siklus $40.4 \%$, mengalami peningkatan pada siklus I sebesar $18.04 \%$ menjadi $58.44 \%$ dan pada siklus II meningkat sebesar $23.06 \%$ menjadi $81.5 \%$.

Hasil penelitian Chresty Anggreani Jurnal Pendidikan Usia Dini Volume 9 Edisi 2, November 2015 menunjukkan rerata kelas pada pra tindakan sebesar $40,27 \%$, setelah siklus I meningkat menjadi sebesar $56,03 \%$ dan pada siklus 2 meningkat menjadi $88,48 \%$. Hasil penelitian menunjukan metode eskperimen berbasis lingkungan dapat meningkatkan kemampuan berpikir kritis anak, terbukti hasil pengamatan yang dilakukan mencapai indikator keberhasilan sebesar $71 \%$.

Hasil penelitian terdahulu tentang pengaruh pola asuh demokratis terhadap kecerdasan jamak, metode kunjungan lapangan terhadap kecerdasan naturalis dan metode eksperimen terhadap kemampuan berpikir kritis, sangat relevan dengan penelitian tentang pengembangan nilai personal. Pada kajian ini nilai personal memiliki 
Pembelajaran Menggunakan Media... Ni Wayan Rasmini

aspek pengembangan emosi, intelek, imajinasi, rasa sosial, rasa etis, dan nilai religius. Ekspresi nilai personal tersebut dapat diamati dalam bentuk kecerdasan jamak, seperti: kecerdasan fisik-motorik, verballinguistik, naturalis, intrapersonal, interpersonal, estetis, dan religius. Dari segi aspek nilai personal dalam penelitian ini jauh lebih komplek dan lengkap dari hasil-hasil penelitian terdahulu, serta metode yang dipakai merupakan metode kualitatif, sedangkan metode-metode penelitian terdahulu sebagian besar menggunakan metode kuantitatif. Sastra tradisional sebagai aspek yang berasosiasi dengan nilai personal merupakan kekayaan warisan leluhur yang memiliki nilai-nilai kemanusiaan, kecintaan terhadap alam dan nilai-nilai keyakinan terhadap pencipta, dimana manusia menjadi sentra dan subjek dari harmonisasi manusia, alam dan Tuhan.

Penelitian ini bertujuan untuk: Mengetahui karakteristik rencana pelaksanaan pembelajaran (RPP) dalam pengembangan nilai personal anak usia dini menggunakan media sastra tradisional; karakteristik proses pembelajaran menggunakan media sastra tradisional dalam mengembangkan nilai personal anak usia dini; dan implikasi pembelajaran menggunakan media sastra tradisional terhadap pengembangan nilai personal anak usia dini di TK Cahaya Ananda Mataram.

\section{METODE PENELITIAN}

Penelitian ini menggunakan pendekatan deskriptif kualitatif, diawali dengan menentukan focus dan sub-fokus, subjek dan objek penelitian sesuai dengan masalah yang akan dipecahkan. Penelitian ini dilakukan di TK Cahaya Ananda Mataram, Cakranegara, Kota Mataram. Lokasi ini dipilih karena semua siswa yang beragama Hindu dan pembelajarannya banyak menggunakan media sastra tradisional. Waktu penelitian direncanakan selama 5 (lima) bulan, mulai bulan April sampai Agustus 2016. Sumber data primer dalam penelitian ini adalah Kepala Sekolah, guru dan siswa di TK Cahaya Ananda Mataram. Sumber data sekunder dalam penelitian ini adalah dokumen 
Pembelajaran Menggunakan Media... Ni Wayan Rasmini

sekolah, RKH, RKM, dan dokumen lain yang mendukung.

Teknik pengumpulan data menggunakan observasi, wawancara, FGD dan analisis dokumen. Teknik analisa data yang digunakan adalah analisa data kualitatif. Menurut Milles dan Huberman (dalam Sugiyono, 2012: 337-345), Aktivitas dalam analisis data kualitatif dilakukan secara interaktif dan berlangsung secara terus menerus sampai tuntas, sehingga datanya jenuh. Aktivitas dalam analisis data yaitu data reduction, data display dan conclution drawing/verification.

Pengujian keabsahan data pada penelitian ini menggunakan: 1) teknik Triangulasi. Data yang diperoleh dengan wawancara, lalu dicek dengan observasi, dokumentasi, atau kuesioner. 2) Kredibiltas (credibilty) dimana hasil penelitian ini dapat dipercaya oleh partisipan, 3) Transferabilitas (transferability) yang merujuk pada kekuatan hasil penelitian untuk ditrasfer pada konteks yang lain, dan 4) Komfirmabilitas (confirmability) menuntut pada kekuatan hasil penelitian yang dikomfirmasi oleh orang lain.

\section{HASIL PENELITIAN DAN PEMBAHASAN}

\section{Rencana Pelaksanaan Pembelajaran (RPP) dalam Mengembangkan Nilai Personal Anak Usia Dini Menggunakan Sastra Tradisional sebagai Media Pembelajaran}

Hasil penelitian menemukan RPP yang digunakan sebagai acuan dalam pelaksanaan pembelajaran di TK Cahaya Ananda Mataram. Format RPP mengikuti format yang ada pada Permen 58 atau 137 yang berlaku untuk Rencana Pelaksanaan Pembelajaran Harian (RPPH) dan Rencana Pelaksanaan Pembelajaran Mingguan (RPPM). Komponen yang khas pada RPPH yang berorientasi pengembangan nilai personal anak usia dini adalah: 1) tema/sub tema; 2) indikator; 3) kegiatan; 4) alat dan bahan; 5) penilaian hasil belajar.

Karakteristik tema yang relevan digunakan sebagai materi pembelajaran dan permainan dalam pengembangan nilai personal ialah tema yang berkaitan dengan diri sendiri, lingkungan dan keagamaan. 
Pembelajaran Menggunakan Media... Ni Wayan Rasmini

Tema tentang diri sendiri maupun tentang lingkungan baik lingkungan keluarga, sekolah dan masyarakat serta lingkungan alam seperti binatang dan tumbuh-tumbuhan diambil dalam kemasan sastra tradisional baik lisan maupun tulisan. Fabel tentang Sang Kancil dan Buaya yang dimenangkan oleh Kancil yang cerdik, memuat pengembangan nilainilai sosial, moral, kepemimpinan, emosi, kognitif, bahasa, seni, etis dan religius pada anak usia dini. Berdasrkan rumusan tema yang dikonstruksi oleh guru dapat mengembangkan pribadi anak yang utuh sebagai individu, anggota masyarakat, dan agen pelestarian lingkungan.

Hasil analisis terhadap RPPH yang dibuat oleh guru menemukan bahwa indikator hasil belajar untuk mengembangkan nilai personal anak terdiri dari sikap disiplin, jujur, bertanggung jawab, kerjasama, kekompakan, dan sportivitas. Sedangkan untuk pengembangan diri terdiri dari beberapa indikator yaitu: mengembangkan rasa ingin tahu, rasa percaya diri, dan peningkatan kemampuan konsentrasi. Indikator hasil belajar tentang pengembangan nilai personal anak yang dibuat oleh guru, telah memadai secara konsep, struktur dan isi, tetapi perlu disempurnakan, dilengkapi, secara lebih koprehensif berorientasi pada pengembangan nilai personal yaitu: aspek emosi, intelek, imajinasi, empati, etis dan religius.

Kegiatan pembelajaran pada umumnya di PAUD disesuaikan dengan tema, dan kebutuhan tumbuhkembang anak. langkah-langkah kegiatan terdiri dari 4 langkah pokok, yaitu: a) pijakan lingkungan bermain (30 menit); b) pijakan sebelum bermain (30 menit); c) pijakan selama bermain (60 menit); d) pijakan setelah bermain (30 menit). RPPH yang dibuat oleh guru di PAUD Cahaya Ananda belum mengikuti format langkah-langkah kegiatan pembelajaran sebagaimana mestinya, akibatnya proporsi waktu dalam langkah-langkah pembelajaran belum dapat dilaksanakan dengan baik, seperti pola 30 menit, 30 menit, 60 menit dan 30 menit. Pelanggaran struktur pembelajaran seperti ini mengakibatkan standar pelaksanaan pembelajaran tidak dapat dicapai 
Pembelajaran Menggunakan Media... Ni Wayan Rasmini

dengan baik. Langkah pembelajaran menggunakan sastra tradisional untuk mengembangkan nilai personal perlu dilakukan secara hirarki mulai dari melakukan pijakan lingkungan main, pijakan sebelum main, pijakan selama main dan pijakan setelah main. Langkah-langkah pembelajaran ini mengandung nilai prasyarat tingkah laku yang harus dilakukan secara berurutan agar tumbuh-kembang nilai personal anak diperoleh secara optimal. Komponen penilaian pembelajaran belum direncanakan dengan memadai terutama pemilihan indikator hasil belajar yang representatif, pemilihan teknik penilaian dan instrument yang tepat, dan teknik analisis penilaian yang akurat.

\section{Pelaksanaan Pembelajaran Menggunakan Media Sastra Tradisional dalam Mengembangkan Personal Anak Usia Dini}

a) Pijakan lingkungan main (30 menit) guru melakukan seting kelas, dan guru mempersiapkan kegiatan main menggunakan prinsip: lihat, dengar dan lakukan. Permainan yang dipilih dalam pembelajaran ini adalah lagu senyum dan lagu tultaltil, serta cerita tentang harimau menantang manusia. Kegiatan ini dilaksanakan diawali dengan menyampaikan materi untuk didengar oleh semua anak, menunjukkan gambar atau benda untuk dilihat oleh semua anak dan selanjutnya guru mengajak masing-masing anak untuk melakukan kegiatan-kegiatan yang berkaitan dengan keterampilan hidup dan kewajiban hidup sehat sebagai makhluk individu, sosial dan Tuhan.

b) Pijakan sebelum main (30 menit) anak-anak diajak berdoa sebelum melaksanakan kegiatan bermain dan bernyanyi. Tanya-jawab sebagai bahan apersepsi tentang pengetahuan awal anak-anak terhadap beberapa aspek nyanyian dan cerita yang akan diajarkan.

c) Pijakan selama main (60 menit) anak bermain sesuai dengan kesepakatan yang dibuat bersama guru. Kegiatan pertama dilakukan dengan bernyanyi tultaltil, yang diawali oleh guru dan secara sedikit demi sedikit anak menirukan baik syair maupun nada. Kegiatan bernyanyi dilakukan berulang-ulang sampai dengan anak-anak sebagian besar anak hapal dengan syair dan 
Pembelajaran Menggunakan Media... Ni Wayan Rasmini

nada lagunya. Berikutnya lagu dinyanyikan secara holistik menggunakan perasaan dan pelibatan emosi secara maksimal untuk memaknai lagu itu sesuai dengan temanya. Berikutnya anak-anak diajak menyimak makna dari lagu tersebut, sehingga pembelajaran dengan bermain dapat menumbuhkembangkan emosi senang, gembira, sedih, mengembangkan intelek, membangun imajinasi, menumbuhkan rasa empati dan mempertebal rasa estetika dan muncul nilai-nilai religiusitas.

Lagu tultaltil bermakna kalau suka memelihara itik berilah makan, mengandung efek pengiring yang cukup banyak, di antaranya ada kewajiban manusia untuk memlihara binatang atau makhluk hidup, menyayangi sesama ciptaan Tuhan, memahami keterbatasan binatang, belajar berapiliasi dan berempati terhadap sesama makhluk yang tertimpa musibah, memahami kebutuhan dari makhluk hidup dan mengerti bahwa manusia yang memerlukan makhluk lain bukan hanya makhluk lain yang memerlukan manusia. Lagu tultaltil yang dinyanyikan dengan baik dan benar bisa mengembangkan nilai personal anak, seperti bahwa hidup seseorang memerlukan hobi dan perasaan senang.

Sebagaimana pengamatan pembelajaran yang pertama bahwa langkah-langkah pembelajaran, yaitu: pijakan lingkungan main, pijakan sebelum main, pijakan main dan pijakan setelah main. Kegiatan pembelajaran inti, yaitu anak-anak main sesuai dengan kesepakatan, pembelajaran diawali oleh cerita guru tentang harimau menantang manusia dengan urutan cerita yang sistematis, menggunakan alun suara sesuai dengan peran dalam cerita. Pemeran cerita terdiri dari Harimau sebagai raja hutan yang keras, tegas, otoriter dan emosional, tetapi kurang cerdik. Peran yang kedua adalah Gajah sebagai warga kerajaan hutan yang lugu, polos, tetapi cerdik dan luwes. Peran yang ketiga adalah manusia yang bernama I Wiweka sebagai pencari kayu api di hutan dan I Sagnata yang secara simbolis ditempatkan sebagai pemeran pemburu yang hebat yang sudah 
banyak membunuh harimau dan jenis binatang lainnya.

Keberhasilan pembelajaran menggunakan cerita Harimau menantang manusia dapat membangun tumbuh-kembang nilai personal secara efektif dan efisien. Anak-anak dapat bangkit emosinya dalam menyimak masing-masing peran dalam cerita. Anak dapat berkembang intelektualnya, bahwa mereka mampu menjawab masingmasing pemeran dalam cerita. Anak dapat tumbuh empatinya terhadap gajah yang senantiasa dihina oleh Harimau. Anak dapat tumbuh imajinasinya untuk mereka pingin seperti peran gajah dan tidak pingin seperti Harimau. Anak tumbuh perkembangan moral/etis dari ucapan dan rendah diri si gajah waktu menghadapi rajanya (Harimau) dan anak mulai berkembang kemampuan religius dengan menunjukkan sikap iba atau kasian terhadap ketidakadilan, ketidaksamaan hak, dan alur komunikasi yang otoriter antara Harimau dengan jenis binatang lainnya.

\section{Implikasi Pembelajaran Menggunakan Media Sastra Tradisional}

\section{Mengembangkan Nilai Personal Anak Usia Dini}

Nilai personal anak dikelompokkan menjadi beberapa aspek seperti: emosi, intelek, imajinasi, empati, etis dan religius. Anak mengidentifikasi dirinya kepada tokoh protagonis dalam cerita, sehingga sikap dan tingkah laku tokoh itu seolah-olah diadopsi menjadi sikap dan tingkah lakunya. Dengan demikian baik langsung maupun tidak langsung dengan mendengar cerita itu, anak belajar bersikap dan bertingkah laku secara benar. Anak akan belajar mengelola emosi agar tidak merugikan diri sendiri dan orang lain. Perkembangan intelektual, lewat cerita, anak tidak hanya memperoleh kehebatan kisah yang menyenangkan dan memuaskan hatinya. Urutan cerita/kejadian yang mengandung logika pengurutan, logika pengaluran, yang memperlihatkan hubungan antar peristiwa yang diperani oleh tokoh protagonis maupun antagonis dapat diinternalisasi oleh anak.

Pertumbuhan rasa sosial, cerita mendemonstrasikan bagaimana tokoh berinteraksi dengan sesama dan lingkungan, tokoh-tokoh 
Pembelajaran Menggunakan Media... Ni Wayan Rasmini

bekerjasama, saling membantu, Temuan penelitian ini sesuai bermain bersama, melakukan dengan konsep tentang belajar, yaitu aktivitas bersama, membantu belajar diukur berdasarkan perubahan mengatasi kesulitan orang lain, dan lain-lain, yang berkisah tentang kehidupan bersama dalam masyarakat. Cerita sastra yang mengeksploitasi kehidupan bersosial secara baik mampu menjadikan contoh bertingkah laku sosial kepada anak sebagaimana aturan sosial yang berlaku.

Demonstrasi kehidupan yang secara konkrit diwujudkan dalam tingkah laku tokoh, didalamnya juga terkandung sikap etis dan religius. Dalam sebuah cerita, biasanya menampilkan seluruh aspek personalitas manusia, hanya saja terdapat penekanan aspek yang dominan. Cerita yang dimaksudkan untuk menunjang perkembangan perasaan, sikap etis dan religius, maka aspek tersebutlah yang terlihat dominan. Bahkan dalam cerita anak yang jangkauan berpikir dan bernalarnya masih terbatas, maka pembentukan nilai-nilai personal tersebut terlihat langsung atau sedikit terselubung dalam karakter dan tingkah laku tokoh. relative permanen dan tidak secara langsung terjadi setelah proses belajar selesai. Pembelajaran yang terjadi di TK Cahaya Ananda juga relevan dengan teori belajar Albert Bandura, teori belajar ini melahirkan teori belajar sosial atau teori belajar model dalam Hergenhahn \& Matthew $\mathrm{H}$. Olson (2010: 360). Pada prinsipnya anak belajar melalui imitasi dan observasional. Bandura menyatakan belajar observasional mungkin menggunakan imitasi atau mungkin juga tidak.

Hal ini kelihatan terlaksana di TK Cahaya Ananda tentang belajar obsevasional berlaku untuk prilaku yang diinginkan maupun prilaku yang dihindari, tetapi belajar imitasi hanya digunakan untuk meniru objek yang diinginkan atau yang positif. Hasil penelitian terdahulu Yenti Juniarti 2016 menemukan bahwa kecerdasan naturalis dapat meningkat dengan metode kunjungan lapangan dan dan kemampuan berpikir kritis anak dapat meningkat dengan metode 
Pembelajaran Menggunakan Media... Ni Wayan Rasmini

eksperimen berbasis lingkungan.

Berarti tumbuh-kembang anak dalam kecerdasan naturalis maupun kemampuan berpikir kritis dapat dipengaruhi oleh kegiatan pembelajaran yang berbasis lingkungan.

Maka dengan demikian teoriteori yang dibangun oleh para ahli pendidikan dan pembelajaran selama ini didukung oleh hasil penelitian, bahwa pengembangan nilai personal dapat dilakukan dengan pembelajaran menggunakan media sastra tradisional.

\section{KESIMPULAN}

Karakteristik RPPH yang ditemukan dalam penelitian ini telah mengikuti format RPPH yang sedang berlaku, dengan komopen-komponen pokok: tema dan sub-tema, hasil belajar dan indikator hasil pembelajaran, metode dan media pembelajaran, teknik evalusai dan penilaian pembelajaran

Karakteristik pelaksanaan pembelajaran di TK Cahaya Ananda Mataram ditemukan ditempat penelitian menunjukkan bahwa langkah pijakan orientasi lingkungan dan sebelum main digabungkan menjadi kegiatan awal di luar kelas. Akibatnya orientasi fisik dan mental anak terhadap pembelajaran inti agak lemah, hal ini dapat membuat kesiapan anak memasuki kegiatan inti atau pijakan main menjadi terganggu sehingga intensitas pembelajaran menjadi lemah. Pijakan setelah main yang semestinya digunakan sebagai kegiatan mengevaluasi pembelajaran dan pengamatan terhadap pengembangan prilaku yang terjadi karena pelaksanaan pembelajaran belum dilakukan secara terstruktur sehingga hasil belajar harian tidak secara rutin dapat dilaporkan kepada pihak-pihak yang memerlukan.

Implikasi pembelajaran menggunakan media sastra tradisional dalam menumbuhkembangkan nilai personal anak usia dini di TK Cahaya Ananda Mataram. Beberapa pembelajaran yang menggunakan media sastra tradisional seperti nyanyian terdisional, cerita binatang dan kebiasaan-kebiasaan tradisional masyarakat sekitar yang diinternalisasi oleh guru menjadi rencana pembelajaran dan 
Pembelajaran Menggunakan Media...

Ni Wayan Rasmini

pelaksanaan pembelajaran, ternyata dapat memberi dampak pada tumbuhkembang niali personal anak. Dalam proses belajar dan diakhir pembelajaran dapat diamati tingkah laku anak seperti: emosi, intelek, imajinasi, empati, etis dan religius.

\section{Saran}

Diharapkan kepada guru dan pengelola TK/PAUD untuk mentaati peraturan yang berlaku tentang aspekaspek rencana kegiatan pembelajaran dan langkah-langkah implementasi rencana pembelajaran agar persiapan dan pelaksanaan pembelajaran terstandar dengan baik.

Penelitian ini hanya dilakukan di TK Cahaya Ananda Mataram, diharapkan pada peneliti lain melakukan penelitian dengan aspek yang lebih luas, informan yang lebih banyak mengenai sastra tradisional sebagai media dalam menumbuhkemabangkan nialai personal anak agar terjadi peningkatan keabsahan hasil penelitian, singga memilik nilai ilmiah yang lebih tinggi

\section{DAFTAR PUSTAKA}

Anggreani, Chresty. 2015. Peningkatan Kemampuan Berpikir Kritis Melalui

Metode Eksperimen Berbasis Lingkungan. JURNAL PENDIDIKAN USIA DINI PPs UNJ. Volume 9 Edisi 2, November 2015 diakses 8 Agustus 2016

Hergenhahn, B.R. \& Matthew H. Olso. 2010. Edisi Ketujuh Theories of Learning (Teori Belajar) Dialihbahasakan oleh Tri Wibisono B.S. Jakarta: Kencana.

Isjoni. 2010. Model Pembelajaran Anak Usia Dini. Bandung: ALFABETA.

Juniarti, Yenti. 2015. Peningkatan Kecerdasan Naturalis Melalui Metode Kunjungan Lapangan (Field Trip). JURNAL PENDIDIKAN USIA DINI PPs UNJ. Volume 9 Edisi 2, November 2015 diakses 8 Agustus 2016

Mafiroh. 2009. Strategi Pembelajaran Efektif. Semarang: PT. SINDUR PRESS.

Mitcell, Diana. 2003. Children's Literature, an Invitation to the Word. Boston: Ablongman.

Muhaimin Azzet, Ahmad. 2011. Mengembangkan Kecerdasan Sosial Bagi Anak. Jogjakarta: KATAHATI.

Mulyasa, E.H. 2009. Implementasi Kurikulum Tingkat Satuan Pendidikan. Jakarta: Bumi Aksara

Nurgiyantoro, Burhanudin 2005. Sastra Anak (Pengantar Pemahaman Dunia Anak). Yogyakarta: Gajah Mada University Press.

Rasmini, Ni Wayan, 2015. Pola Pengasuhan dan Kecerdasan 
Pembelajaran Menggunakan Media...

Ni Wayan Rasmini

Jamak Anak Usia Dini Dalam

Keluarga Hindu Di Kota

Mataram. Mataram: Hasil

Penelitian

Sadiman S. Arif, dkk. 2012. Media

Pendidikan

Pengertian,

Pengembangan,

dan

Pemanfaatannya

Sugiyono. 2012. Metode Penelitian

Kuantitatif, Kualitatif dan

$R \& D$. Bandung: Alfabeta.

Sukatman. 2009. Butir-butir Tradisi

Lisan Indonesia. Yogyakarta:

Laksbang Pressindo.
Surya, Sutan. 2006. Melejitkan

Multiple Intelligence Sejak

Dini. Yogyakarta: CV ANDI OFFSET.

Wibowo, Agus. 2012. Pendidikan Karakter Usia Dini (strategi Membangun Karakter di Usia Emas). Yogyakarta: PUSTAKA PELAJAR.

Wiyani, Novan \& Barnawi, 2012. Format PAUD. Jakarta: ARRUZZ MEDIA. 